\title{
THE ISSUE OF SOVEREIGNTY IN AN EVER-CLOSER UNION
}

\begin{abstract}
Tina Oršolić Dalessio*
Summary: This paper aims to answer the following question: what is the understanding of the principle of sovereignty in the EU today, and how should this knowledge inform our actions tomorrow? It is demonstrated that from both doctrinal and practical points of view, it is impossible to determine conclusively what sovereignty or its preservation entails in the present European legal setting. The only point of clarity regarding the contemporary interpretation of sovereignty is that the principle should no longer be conceived in traditional and absolute terms - since this would be incompatible with the current European legal and political reality. Yet, while there seems to be an agreement on what sovereignty is not, there is no agreement, in either legal doctrine or practice, on what this principle actually is. It is argued that such a deeply contested nature of sovereignty puts in question not only the role and strength of this principle, but also the adequacy of its use as a legal parameter for determining the boundaries of the European integration process. It is thus concluded that in legal debates concerning the future of the EU, arguments relying on sovereignty should not be taken at face value. Rather, they should be approached with a critical eye and with full awareness of the disputed nature of the principle they rest upon.
\end{abstract}

\section{Introduction}

Sovereignty and the safeguarding thereof have been the subject of heated debates since the beginning of European integration. Some have used it as an argument in favour of quantitative and qualitative expansion of the European Union, others as an argument against it, and others still have dismissed sovereignty as an outdated legal construct. All of this has, in turn, generated confusion regarding the contemporary understanding of the principle of sovereignty in the European legal context.

Senior lecturer in the Department of Legal Theory, Faculty of Law, University of Zagreb. I would like to express my gratitude to Kenneth Einar Himma, Luka Burazin and the participants of the 2014 CEE Forum of Young Legal, Political and Social Theorists for their valuable comments on the earlier drafts of this paper. This paper was written within the framework of the Project 'Znanstvenoistraživački projekt Pravnog fakulteta Sveučilišta u Zagrebu'. The usual disclaimer applies. 
The aim of this paper is to determine what the present stance on the principle of sovereignty in the EU from a legal point of view is, and what lessons this teaches us for the future. In particular, the author will seek to find out how legal doctrine and legal practice conceive sovereignty in Europe today, and how this should inform our debate tomorrow.

In order to uncover the contemporary legal understanding of sovereignty in Europe, the author will first look at the doctrinal take on this principle and its development. She will then turn to the relevant judicial practice dealing with the principle of sovereignty and its safeguarding in the European integration context.

It will be shown that both in legal doctrine and practice, the principle of sovereignty is surrounded by much dispute and ambiguity. The only point of clarity and consensus seems to consist in the rejection of the oldfashioned, inflexible understanding of sovereignty conceived in terms of absolute and indivisible powers. Yet, while both legal scholars and practitioners seem to agree on what sovereignty does not comprise, there is no agreement on how this principle should be properly construed.

The author will argue that the vagueness and confusion surrounding the principle of sovereignty is instructive in several ways. First, the profoundly disputed and diluted character of sovereignty puts into question the role, strength and credibility of this legal principle. By extension, such a nature of sovereignty raises the issue of the potency and persuasiveness of arguments based on this principle. That is to say, due to the fundamental ambiguity and disagreement surrounding sovereignty, references to this principle seem to obscure, rather than clarify, the legal answers to practical questions faced in the European integration process.

Second, the deeply contested nature of the principle of sovereignty raises doubts about the adequacy of its use as a legal parameter for deciding the present and the future of the European Union. As things stand, the principle of sovereignty provides fertile grounds for arbitrary and non-transparent decision-making. Its acknowledged profoundly disputed character and the possibility of endorsing its conflicting interpretations depending on the circumstances and interests involved render it an ideal instrument for passing policy judgments under the pretence of legal objectivity.

This teaches us an important lesson. Arguments based on sovereignty should not be taken for granted - especially not when they are aimed at steering the European integration process. Rather, they should be approached with caution, awareness of the vagueness of the principle they rest upon, and an understanding that its varying, yet equally feasible, interpretations can generate conflicting results of legal analysis. 


\section{Sovereignty in legal doctrine}

The concept of sovereignty was first comprehensively elaborated by Jean Bodin in his famous Les Six livres de la République dating back to 1576. Bodin described sovereignty as an absolute, indivisible and perpetual power of giving law and issuing commands to all in general and to each in particular. ${ }^{1}$ This power, according to him, exists 'without consent of any other'. ${ }^{2}$

Bodin's account of sovereignty was more prescriptive than descriptive, more of an ideal than the actual depiction of the distribution of powers in sixteenth-century France. ${ }^{3}$ At the time it was made, this theory was meant to serve a practical political purpose - it was envisaged as a way of strengthening the French monarchy in the circumstances of the severe political crisis caused by the wars of religion. ${ }^{4}$ Yet, as the circumstances have since changed, so has the understanding of sovereignty.

Most scholars nowadays agree that Bodin's theory of sovereignty comprises fatal flaws. ${ }^{5}$ As Eleftheriadis explains, Bodin's account of sovereignty is viewed as a descriptive failure since it fails to capture the fluidity and elusiveness of political power. ${ }^{6}$ In addition, Bodin's theory of sovereignty is regarded as a normative failure as its fails to provide convincing reasons why we should be at the mercy of the absolute sovereign prince. $^{7}$

Yet, while there seems to be rather wide agreement amongst legal scholars regarding the inadequacy of Bodin's conception of sovereignty, there is no agreement on what is the adequate, proper account of sover-

\footnotetext{
1 See Jean Bodin, On Sovereignty: Four Chapters from the Six Books of the Commonwealth (Julian H Franklin ed, CUP 1992) book 1, chs 8 and 10.

2 ibid 56. Bodin clarified that the power of making and repealing law entails all the other rights and prerogatives of sovereignty. Particularly, it includes the power of declaring war and making peace, establishing principal officers of state, judging in last instance, granting pardons and dispensations against the rigour of the law, coining money, fealty and liege homage, and laying taxes on subjects, or exempting some of them. See ch 10.

3 Edward Andrew, 'Jean Bodin on Sovereignty' (2011) 2(2) Republics of Letters 75, 84 <http:/ / arcade.stanford.edu/sites/default/files/article_pdfs/roflv02i02_Andrew_060111_0.pdf> accessed 8 October 2014

4 ibid.

5 See Pavlos Eleftheriadis, 'Law and Sovereignty' $1<$ http://www.trinitinture.com/documents/eleftheriadis2.pdf> accessed 8 October 2014. Also see Julian H Franklin, 'Sovereignty and the Mixed Constitution: Bodin and his Critics' in JH Burns and M Goldie (eds), Cambridge History of Political Thought 1450-1700 (CUP 1995) 298.

6 See Eleftheriadis (n 5) 1. As Raz argued nearly half a century ago, sovereignty can be divided into, as well as shared between, separate, non-subordinate bodies. See Joseph Raz, The Concept of a Legal System: An Introduction to the Theory of Legal System (Claredon Press 1980) chs I and II. See also Julie Dickson and Pavlos Eleftheriadis, Philosophical Foundations of European Union Law (OUP 2012) 85.

7 Eleftheriadis (n 5) 1.
} 
eignty. In other words, while most scholars seem to agree on what sovereignty is not, they fail to agree on what it is.

The lack of consensus on the proper interpretation of the principle of sovereignty in European legal doctrine started to evolve shortly after Bodin presented his theory. Following his explanation of what sovereignty is (or should be), this legal construct evolved in two ways, broadly speaking. In continental Europe, Bodin's original account transformed into the principle of popular sovereignty, while in Great Britain it took the form of the principle of parliamentary sovereignty. ${ }^{8}$

The principle of popular sovereignty was developed under the influence of contractarian theories and the $18^{\text {th }}$ century American and French Revolutions. ${ }^{9}$ In particular, it was Jean-Jacques Rousseau's social contract theory that largely defined the contours of this principle, also known as the sovereignty of the people. ${ }^{10}$

Unlike Thomas Hobbes who had previously argued that individuals, by entering society, give up their sovereignty entirely in favour of a prince who then becomes an absolute sovereign, ${ }^{11}$ Rousseau's vision of the social contract was more liberal. According to Rousseau, the people, as sovereign, retain the ultimate power to impose the laws while delegating the power to enforce them to the Government/the Prince. ${ }^{12}$ The Government, thus, represents merely a minister of the sovereign people, who review its accountability and renew its mandate. ${ }^{13}$ Opposite to Hobbes' theory under which it could be said that the state 'swallows' the people, under Rousseau's social contract theory, the people 'swallow' the state through the exercise of the general will. ${ }^{14}$ As a result, the principle of the sovereignty of the people finds solid ground and justification under the latter theory.

Thus, the idea underlying the principle of popular sovereignty is that people represent the ultimate source of political and legal authority within a state territory. This principle, in other words, is based on the belief

\footnotetext{
8 See Bruno de Witte, 'Sovereignty and European Integration: The Weight of Legal Tradition' in Anne-Marie Slaughter, Alec Stone Sweet and JHH Weiler (eds), The European Court and National Courts: Doctrine and Jurisprudence (Hart Publishing 1998) 279.

9 ibid.

10 See Ken Endo, 'Subsidiarity and its Enemies: To What Extent Is Sovereignty Contested in the Mixed Commonwealth of Europe?' (2001) EUI Working Paper RSC No 2001/24, 5, 27; András Jakab, 'Neutralizing the Sovereignty Question: Compromise Strategies in Constitutional Argumentation before European Integration and Since' (2006) 2 EuConst, 375, 377.

11 See Thomas Hobbes, Leviathan, (CB Macpherson ed, Penguin Books 1968) ch XVIII.

12 See Jean-Jacques Rousseau, The Social Contract and Other Later Political Writings (Victor Gourevitch ed, CUP 1997) book III, ch I.

13 ibid.

14 Alain de Benoist, 'What is Sovereignty?' (Julia Kostova tr) taken from 'Qu'est-ce que la souveraineté?' (1999) 96 Éléments 24, 104.
} 
that 'all political and legal power ought to rest on the will and consent of those among and over whom power is exercised'. ${ }^{15}$

Regardless of possible nuances in its interpretation, it can be concluded that this understanding of sovereignty and all its varying applications ultimately belong to the theory of democracy. ${ }^{16}$ What therefore lies at the core of popular sovereignty is the affirmation of the people's right to self-determination and self-governance, ${ }^{17}$ exercised through their rights to democratic participation and representation.

In this regard, it is worth noting that popular sovereignty does not imply or presume the existence of any constitutional state organ enjoying sovereignty. ${ }^{18}$ On the contrary, it is the absence of the latter that forces us to identify the people as the ultimate possessor of the sovereignty of their state'. ${ }^{19}$

On the other hand, when it comes to the second main 'successor' of Bodin's original idea of sovereignty in Europe, things are quite different. Under the principle of parliamentary sovereignty, or at least its legal conception, it is recognised that sovereignty resides precisely in an institution. ${ }^{20}$ As apparent from its very name, the principle of parliamentary sovereignty suggests that Parliament is the repository of legal sovereignty'. ${ }^{21}$ More specifically, in the case of Great Britain, it suggests that the Parliament composed of three bodies acting jointly - the House

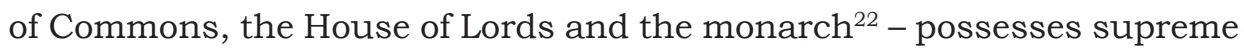
legal power to make or unmake any law. ${ }^{23}$

This principle, dominant in Great Britain, implies furthermore that no body or person has the right to override, hold invalid or set aside the legislation of Parliament. ${ }^{24}$ The only legal limitation of Parliament's legislative power is that 'a parliament of today cannot, with legislation, bind a

\footnotetext{
15 Neil MacCormick, Questioning Sovereignty: Law, State, and Nation in the European Commonwealth (OUP 1999) 130.

16 ibid.

17 Popular sovereignty can, in MacCormick's words, be described as 'sovereignty as selfdetermination' ibid 134.

18 ibid 130.

19 ibid 131. However, as MacCormick further explains, for the people to count as the ultimate possessor of sovereignty, there needs to exist some constitutional grounding.

20 de Witte (n 8) 279.

21 MacCormick (n 15) 133.

22 When acting together, these three bodies are referred to as the 'King in Parliament' (currently, the 'Queen in Parliament'). See Jeffrey Goldsworthy, The Sovereignty of Parliament: History and Philosophy (Clarendon Press 1999) 9; and Albert Venn Dicey, Introduction to the Study of the Law of the Constitution (Liberty Fund 1982) 3.

${ }^{23}$ Dicey (n 22).

24 ibid 3, 4. See also Goldsworthy (n 22) 10.
} 
parliament of tomorrow'. ${ }^{25}$ That is to say, Parliament must be at liberty to ignore its own previous laws whenever it passes a new one. ${ }^{26}$ This is also known as the doctrine of implied repeal.

Just as with any other legal principle, there are certain disagreements as to parliamentary sovereignty's defining features, such as its origins, the exact extent of the permissible legislative self-restraint and the possibilities of expounding this concept in the future. ${ }^{27}$ However, regardless of these differences in interpretation, it can be more or less unequivocally concluded that the orthodox legal understanding of parliamentary sovereignty, ${ }^{28}$ unlike its rival conception of popular sovereignty, suggests that people are not and could not be considered as sovereign. ${ }^{29}$ The people, that is, the electoral body, have only the right to elect the members of Parliament and can only express themselves legally through Parliament and in no other manner. ${ }^{30}$

Regardless of their points of divergence, however, both the principle of parliamentary sovereignty and that of popular sovereignty have experienced serious challenges in the past century. This was due to the profound changes that European nation-states and their legal systems have gone through.

25 Alec Stone Sweet, 'Constitutional Dialogues in the European Community' in Anne-Marie Slaughter, Alec Stone Sweet and JHH Weiler (eds), The European Court and National Courts, Doctrine and Jurisprudence: Legal Change in Its Social Context (Hart Publishing 1998) 316. See also, for example, Joaquin Varela Suanzes, 'Sovereignty in British Legal Doctrine' (1999) 6(3) Murdoch University Electronic Journal of Law 39; and Goldsworthy (n 22) 16.

26 Jeffrey Goldsworthy, Parliamentary Sovereignty: Contemporary Debates (CUP 2010) 289.

27 For an account of these disagreements, see Goldsworthy (n 26). See also Tina Oršolić, 'Book Review of Jeffrey Goldsworthy, Parliamentary Sovereignty: Contemporary Debates' (2011) 7 European Constitutional Law Review 336.

28 Albert Venn Dicey's elaboration of parliamentary sovereignty is frequently perceived as the orthodox understanding of this principle. See Goldsworthy (n 26) 288. See also Kenneth A Armstrong, 'United Kingdom - Divided on Sovereignty?' in Neil Walker (ed), Sovereignty in Transition (Hart Publishing 2006).

29 Suanzes (n 25) 38.

30 ibid. This, consequently, implies that British courts will take no notice of the will of the electorate. See Dicey (n 22) 28. Dicey, however, acknowledges that 'the electors are a part of and the predominant part of the politically sovereign power' 29 (emphasis added). Thus, if sovereignty is considered strictly as a political, rather than a legal, concept, it may be said that the electors, together with the Crown and the Lords, constitute the body in which sovereign power is vested 27. In a political sense, the concept of sovereignty under the British legal tradition therefore appears somewhat closer to the basic postulates of the concept of popular sovereignty. Dicey himself admits that the legal and the political meaning of the word sovereignty are, in reality, at least equally important 28 . However, he also clearly states that the two conceptions, even though intimately connected, are essentially different and must not be confused. This is precisely the point around which Dicey's criticism of John Austin's theory of sovereignty evolves 26-29. For a more detailed account of Austin's theory of parliamentary sovereignty, see John Austin, The Province of Jurisprudence Determined ( $2^{\text {nd }}$ edn, Burt Franklin 1970) lecture VI. For a distinction between legal and political sovereignty, see further Samantha Besson, 'Sovereignty in Conflict' (2004) 8(15) European Integration online Papers 8-9 <http://eiop.or.at/eiop/texte/2004-015.htm> accessed 8 October 2014. 
The consequences of the two bloodiest and deadliest events of the last century - the First and the Second World War - played the main role in bringing about these changes. These wars taught Europeans a painful and important lesson: independent national dominions cannot provide sufficient guarantees of peace and prosperity for the people who inhabit them. In order to realise these ideals, something more is needed - something extending beyond the national sphere.

Learning this hard lesson has led to the introduction of various international law mechanisms aimed at protecting human rights and fundamental freedoms, establishing basic humanitarian law standards and promoting international cooperation. ${ }^{31}$ Moreover, it marked the beginning of the project that will forever change the face of Europe - the project of European integration.

Over the course of time, the project of European integration has grown in size and scope, turning into a Union that inseparably ties the economies, the politics and the peoples of its Member States. The growth and strengthening of the European Union have facilitated the flow of goods, services, persons and capital across national borders and have attracted a growing membership. Its expansion has ensured the desired attainment of its core objectives - peace, stability and economic growth in post-war Europe. Yet, all of this has come at a certain cost. The gradual development of an ever-closer Union implies the increasing transfer of competences from the national to the supranational level.

Early on, the European Court of Justice described the legal system of this growing Community as 'a new legal order of international law for the benefit of which the states have limited their sovereign right, albeit within limited fields'. ${ }^{32}$ Nowadays, however, there is widespread anxiety that these fields are limited no more. ${ }^{33}$ Some even claim in this context that there is simply no nucleus of sovereignty that the Member States can invoke, as such, against the European Union. ${ }^{34}$

Notwithstanding its positive outcomes, the development of the European integration project has thus created serious challenges for those promoting and believing in the idea of sovereign European nation-states. It has revealed that absolute or unitary sovereignty is entirely absent from the political and legal setting of the European Union. ${ }^{35}$ More specifically,

\footnotetext{
31 Most notably, the United Nations and the Council of Europe legal mechanisms negitioated in the aftermath of the Second World War.

32 See Case 26/62 Van Gend en Loos [1963] ECR 1.

${ }_{33}$ Joseph HH Weiler, 'Federalism and Constitutionalism: Europe's Sonderweg' (2001) Harvard Jean Monnet Working Paper No 10/00, 5.

34 See ibid, citing Koen Lenaerts, 'Constitutionalism and the Many Faces of Federalism' (1990) 38 American Journal of Comparative Law 205, 220.

35 MacCormick (n 15) 132.
} 
it has made it clear that neither politically nor legally is any EU Member State in possession of ultimate power over its own internal affairs, or is it fully sovereign externally. ${ }^{36}$ And neither is the European Union. ${ }^{37}$

The unique European experiment in intertwining national and supranational spheres has therefore exposed traditional conceptions of sovereignty, which sought to lock and confine sovereign powers within national borders, as unsuitable and unsustainable. The choice was either to give them up entirely, or yet again readapt the principle of sovereignty to the new circumstances in which the EU Member States now operate. While some scholars seem to have chosen the former path, others have opted for the latter.

Hence, we find those who deem the European integration process as a cause of the demise of sovereignty in Europe and who welcome the idea of the European sovereignty-free reality. One of the most articulate defenders of the post-sovereign position in the European integration context is Neil MacCormick. ${ }^{38}$ MacCormick has famously argued that the recent developments in Europe have taken us 'beyond the sovereign state' and towards the era of 'post-sovereignty'. ${ }^{39} \mathrm{He}$ has elaborated in this regard that sovereignty is like virginity, something that can be lost by one without another's gaining it - and whose loss in apt circumstances can even be a matter of celebration'. ${ }^{40}$ Accordingly, he welcomed 'the prospect of Europe beyond sovereign statehood'. ${ }^{41}$

More radically, some scholars altogether reject the idea of sovereignty and hold that clinging onto this concept is misguided and possibly dangerous. Eleftheriadis has, for instance, on these lines suggested that the survival of the idea of sovereignty is a mistake, since it cannot be adjusted to fit the age of rights and constitutions. ${ }^{42}$ According to him 'sovereignty is and has always been incompatible with the idea of law', and its survival is purely 'the result of some kind of absent-mindedness on the part of our constitutional lawyers'. ${ }^{43}$

Still, while some bid adieu to or outright reject sovereignty, others continue to recognise its value. Consequently, we witness a growing volume of scholarly work that seeks to reinterpret, readapt or altogether reinvent the principle of sovereignty. The common goal of such scholarly

\footnotetext{
36 ibid.

37 ibid.

38 Neil Walker, 'Late Sovereignty in the European Union' in Neil Walker (ed), Sovereignty in Transition (Hart Publishing 2006) 15.

39 MacCormick (n 15) ch 8.

40 ibid 126.

41 ibid.

42 See Eleftheriadis (n 5).

43 ibid 3, 4.
} 
endeavours is to better fit the principle of sovereignty into the contemporary European legal and political context. Most novel interpretations emerging as a result of these efforts recognise sovereignty's continued existence in the EU, albeit in a more fluid form and at both levels of governance. ${ }^{44}$

Some examples of such interpretations are the conceptions of pooled, shared, mixed, divided, split or partial sovereignty. ${ }^{45}$ These metaphors of 'disaggregation and reaggregation' are all deployed in order to grasp the poly-centred character of the new European configuration of authority. ${ }^{46}$ Broadly speaking, these conceptions portray the sovereignty of EU Member States as something that has not been lost, but subjected to a process of division and combination. ${ }^{47}$

However, 'the attributions of divisibility, alienability, compossibility and mixity' were found by some to sit uneasily with the very sense of sovereignty. ${ }^{48}$ Thus, given their perceived downsides, several scholars have proposed other innovative accounts of sovereignty. For instance, Neil Walker advances the conception of late sovereignty, ${ }^{49}$ Miguel Maduro the idea of competitive sovereignty, ${ }^{50}$ and Samantha Besson the notion of cooperative sovereignty. ${ }^{51}$ Despite their points of divergence, these novel understandings of sovereignty in the EU share a common thread and convey a similar message. They are all aimed at reconciling the principle of sovereignty with the European reality of constitutional pluralism and, for that purpose, insist on the importance of mutual dialogue and the adaptation of sovereign authorities at different levels of governance. ${ }^{52}$

Thus, and notwithstanding some scholars' abandoning of sovereignty in the contemporary European legal context, the list of alternative doctrinal approaches to this legal principle continues to grow. With its growth, the dispute regarding the proper interpretation of the principle of sovereignty grows deeper still.

\footnotetext{
44 In this context, one is bound to wonder whether diluting a concept to the extreme for the sake of preserving it is not somewhat counterproductive.

45 See Walker (n 38) 14-15.

46 ibid.

47 MacCormick (n 15) 133.

48 Walker (n 38) 15. See also de Witte (n 8) 172. De Witte has argued in that sense that if sovereignty is divided, it loses its distinguishing trait.

49 See de Witte (n 8).

50 Miguel Poiares Maduro, 'Contrapunctual Law: Europe's Constitutional Pluralism in Action' in Walker, Sovereignty in Transition (n 38).

51 Samantha Besson, 'Sovereignty in Conflict' (2004) 8(15) European Integration online Papers <http://eiop.or.at/eiop/texte/2004-015.htm> accessed 8 October 2014.

52 See Samantha Besson, 'Book Review of Neil Walker (ed), Sovereignty in Transition' (2005) 3 International Journal of Constitutional Law <http://doc.rero.ch/record/32876/files/ The_Taming_of_Sovereignty.pdf> accessed 8 October 2014.
} 
As things currently stand, one can only conclude that from the point of view of legal doctrine, we keep getting farther and farther from an agreement regarding the meaning and relevance of the principle of sovereignty. The only point of consensus and clarity would seem to be that wherever we are in terms of conceiving sovereignty and its place in today's world, this place is far from where we once started. Therefore, if there is such a thing as sovereignty in the current European legal context, it appears that it can no longer be accurately envisaged in Bodin's terms, as an absolute, indivisible and perpetual power of lawmaking.

\section{Sovereignty in legal practice}

The question remains of what legal practice, as opposed to legal doctrine, tells us about the contemporary understanding of the principle of sovereignty in the EU. Have judges managed to provide more clarity with regard to this principle or are things just as messy in legal practice as they are in legal doctrine?

One should first notice that the question of safeguarding sovereignty in the context of European integration has long been present in judicial practice. In fact, this question has proven central to the national constitutional review of EU law amendments by the highest tribunals of various EU Member States. Thus, in order to determine what the current stance on sovereignty is from the point of view of legal practice, one is bound to look at this line of national constitutional case law.

Thus far, nine highest national courts have engaged in an assessment of the constitutionality of primary EU law amendments. In the course of this review, all of them have insisted on the preservation of the core of sovereignty of their respective states in the process of European integration..$^{53}$

Chronologically, the first to put such emphasis on the need to protect national sovereignty in the European integration context was the Irish Supreme Court in its landmark judgment Crotty $v$ An Taoiseach. ${ }^{54}$ Shortly afterwards, this court's approach was followed by the French Constitutional Council in the Maastricht I case, ${ }^{55}$ the German Federal Consti-

\footnotetext{
53 For a detailed analysis of this judicial approach, see Tina Oršolić Dalessio, Socializing Europe - Solidifying EU Citizneship (Wolf Legal Publishers 2013) ch II.

54 Crotty $v$ An Taoiseach [1987] IESC 4 [1987] IR 713 (9 April 1987) <http://www.bailii. org/ie/cases/IESC/1987/4.html> accessed 8 October 2014.

55 For an English translation, see the French Constitutional Council's Decision 92-308 DC of 9 April 1992, Treaty on European Union (French Maastricht I case) <http://www. conseil-constitutionnel.fr/conseil-constitutionnel/english/case-law/case-law.25743. html>accessed 8 October 2014 .
} 
tutional Court in its famous 'Maastricht-Urteil's6 and the Danish Supreme Court in its Maastricht case. ${ }^{57}$ Following subsequent Treaty amendments, the French Constitutional Council, the Danish Supreme Court and the German Federal Constitutional Court have again had a chance to review primary EU law amendments for their compatibility with national constitutional principles and norms. ${ }^{58}$ On every occasion, these courts have asserted the importance of the principle of national sovereignty and its safeguarding in the process of European integration. ${ }^{59}$ Specifically, they have made it clear that the European Union project can go only as far as it does not infringe upon the core national sovereign powers.

It did not take long before other national tribunals followed this trend of conditioning present and future EU law developments upon the preservation of national sovereignty. The Spanish Constitutional Court applied a similar reasoning in its decision on the Treaty establishing a Constitution for Europe. ${ }^{60}$ And, more recently, this 'sovereignty-related' approach was also applied in the Lisbon Treaty judgments of the Czech

\footnotetext{
56 See Manfred Brunner and Others $v$ European Union Treaty (German Maastricht case) (1994) 1 CMLR 57.

57 See the English annotation by Sten Harck and Henrik Palmer Olsen, 'Decision Concerning the Maastricht Treaty 1998 Ugeskrift for Retsvaesen, H 800' (1999) 93(1) American Journal of International Law 209.

58 See the English translations of the French Constitutional Council's Decision 97-394 DC of 31 December 1997, Treaty of Amsterdam amending the Treaty on European Union, the Treaties establishing the European Communities and certain related instruments; the French Constitutional Council's Decision 2004-505 DC of 19 November 2004, Treaty establishing a Constitution for Europe, both available at <http:/ / www.conseil-constitutionnel.fr/ conseil-constitutionnel/english/case-law/case-law.25743.html > accessed 8 October 2014 and its Decision 2007-560 DC of 20 December 2007, Treaty of Lisbon amending the Treaty on European Union and the Treaty establishing the European Community (French Lisbon Treaty case) <http://www.conseil-constitutionnel.fr/conseil-constitutionnel/english/ case-law/case-law.25743.html> accessed 8 October 2014. See also the Danish Supreme Court Case No 199/2012, Judgment of 20 February 2013 (Danish Lisbon Treaty) Section 3<http://www.domstol.dk/hojesteret/nyheder/ovrigenyheder/Documents / 199-12engelsk.pdf $>$ accessed 8 October 2014, and the German Federal Constitutional Court's Case BVerfG, 2 BvE 2/O8 vom 30.6.2009, Absatz-Nr (1 - 421) (German Lisbon Treaty) <http:// www.bundesverfassungsgericht.de/entscheidungen/es20090630_2bve000208en.html> accessed 8 October 2014.

59 For a detailed analysis, see Oršolić Dalessio (n 53).

60 For an English translation, see Case 6603-2004 before the Spanish Tribunal Constitucional (Spanish EU Constitutional Treaty) (2005) 1 CMLR 39. That 'national sovereignty is vested in the Spanish people' was also affirmed by the Spanish Constitutional Court in its Maastricht case, when the Court was setting the parameters for a review of the compatibility of the Maastricht Treaty with the Spanish Constitution. See Part II, para 3 of the English translation of the Spanish Constitutional Court's Declaration 1/1991 of 1 July 1992 <http://www.tribunalconstitucional.es/fr/jurisprudencia/restrad/Pages/DCC11991en. aspx> accessed 8 October 2014.
} 
Constitutional Court, ${ }^{61}$ the Latvian Constitutional Court, ${ }^{62}$ the Hungarian Constitutional Court ${ }^{63}$ and the Polish Constitutional Tribunal. ${ }^{64}$

While this clearly confirms that sovereignty represents one of the crucial national constitutional principles, the safeguarding of which becomes particularly important in the European integration context, it does not yet clarify what the contemporary legal understanding of this principle is from the practical point of view. The question thus remains: have judges managed to provide us with a clearer and more uniform interpretation of the principle of sovereignty than legal scholars have?

The answer is unfortunately negative. The above-mentioned judgments illustrate that the ambiguity and dispute surrounding the principle of sovereignty is just as present in legal practice as it is in legal doctrine. The only point of consensus from a practical point of view seems to be that sovereignty can no longer be conceived in rigid terms as an absolute and high-handed concept.

The latter has been confirmed by a number of the highest national tribunal decisions reviewing the compatibility of primary EU law amendments with national constitutional principles and norms.

The French Constitutional Council has, in its Maastricht I judgment, affirmed that France may, subject to reciprocity, consent to limitations of its sovereignty that are necessary for the organisation and preservation of peace. ${ }^{65}$ According to the Constitutional Council, this means that France may conclude international agreements aimed at participating in the establishment or development of a permanent international organisation that enjoys legal personality, as well as decision-making powers on the basis of transfers of powers agreed upon by the Member States. ${ }^{66}$

The Danish Supreme Court adopted similar reasoning in its decision concerning the Maastricht Treaty ${ }^{67}$ It ruled that a delegation of sovereign

61 See the English translation of the Czech Constitutional Court's Decision Pl US 19/08 of 26 November 2008 (Czech Lisbon Treaty) <http://www.usoud.cz/en/decisions/?tx ttnews\%5Btt_news\%5D=4848cHash=621d8068f5e20ecadd84e0bae0527552> accessed 8 October 2014.

62 See the English translation of Case 2008-35-01 before the Constitutional Court of Latvia (Latvian Lisbon Treaty) (2010) 1 CMLR 42.

63 See the Press Release on Decision 143/2010 (VII 14) AB of the Constitutional Court of the Republic of Hungary on the constitutionality of the Act of promulgation of the Lisbon Treaty <www.mkab.hu/letoltesek/en_0143_2010.pdf> accessed 8 October 2014.

64 See the English translation of the Polish Constitutional Tribunal's judgment K 32/09 of 24 November 2010 (Polish Lisbon Treaty) <http://trybunal.gov.pl/fileadmin/content/ omowienia/K_32_09_EN.pdf> accessed 8 October 2014.

65 See French Maastricht I case (n 55) para 11.

66 ibid, para 13.

67 To be more exact, this decision dealt with the question of the constitutionality of the ratification and the incorporation into Danish law of the Maastricht Treaty. See the English annotation by Harck and Palmer Olsen (n 57) 209. 
powers to a community of states, such as the EU, is permissible in relation to international authorities established by mutual agreement with other states and for the promotion of international rules of law and cooperation. ${ }^{68}$ The implicit message behind these courts' reasoning seems to be that 'a State can limit or transfer competences, precisely because it is a sovereign State'. ${ }^{69}$

Similarly, the German Federal Constitutional Court (GFCC) asserted that it is fully permissible for the Federal Republic of Germany to become a member of a community of states that acts on its own in sovereign matters and that has the right to exercise independent sovereign powers. ${ }^{70}$ According to the GFCC, the needed conferral of sovereign powers on such a community of states will necessarily result in the exercise of these powers no longer being dependent solely on the will of one Member State. ${ }^{71}$ This means that it is not incompatible with the principle of sovereignty for the German legislature to engage in a far-reaching transfer of sovereign powers to the EU. More recently, this was confirmed and additionally clarified in the GFCC's Lisbon Treaty judgment. There, the Court proclaimed that not only does the German Basic Law support Germany's participation in an integration of states such as the EU, but that it 'abandons a high-handed concept of sovereign statehood that is sufficient unto itself'. ${ }^{72}$

The Czech Constitutional Court's (CCC) Lisbon Treaty case recently further substantiated the conclusion on the abandoning of the traditional, rigid understanding of sovereignty in legal practice. In elaborating the meaning of state sovereignty, the CCC asserted that a transfer of state competences at the EU level does not represent a conceptual weakening of state sovereignty. On the contrary, according to the CCC, it can lead to its strengthening, so long as such a transfer of powers is based on the sovereign's free will and is conditioned by the sovereign's participation in the integration in a manner previously agreed upon and that is reviewable. ${ }^{73}$ In that regard, the $\mathrm{CCC}$ explicitly sought to renounce the traditional, rigid understanding of sovereignty, which presupposes the independence of state power from any other power, in both external and internal matters. ${ }^{74}$ Correspondingly, it confirmed that it is fully in accordance with the constitutional principle of sovereignty for the Czech

68 Carlsen $v$ Rasmussen (Danish Maastricht case) (1999) 3 CMLR 854, para 9.8.

69 Solange Mouthaan, 'France: Amending the Amended Constitution' (1998) 23(6) EL Rev $592,596$.

70 See German Maastricht (n 56), paras 36, 37.

71 ibid, para 37.

72 See German Lisbon Treaty (n 58) para 223.

73 See Czech Lisbon Treaty (n 61) para 108.

74 ibid, para 107. 
Republic to join and take part in an integration of states such as the EU, which requires a transfer of certain sovereign powers to supranational institutions.

The earlier Spanish Constitutional Court's decision on the Treaty establishing a Constitution for Europe applied a similar approach. ${ }^{75}$ While affirming the principle of state sovereignty, the Spanish Constitutional Court acknowledged that the Spanish Constitution allows for the constitutional transfer of powers to the EU. ${ }^{76}$ The same was done by the Constitutional Court of Hungary in its Lisbon Treaty decision, which affirmed that it is possible for the holder of sovereignty, that is, the Hungarian legislator, to limit the exercise of the attributes of sovereignty. ${ }^{77}$

Yet another example of such an approach can be found in the Lisbon Treaty judgment of the Constitutional Court of Latvia. ${ }^{78}$ While recognising the principle of sovereignty as one of the fundamental values upon which the State of Latvia is based, ${ }^{79}$ this Court clarified that the transfer of certain state powers to the EU should be regarded as the exercise of sovereignty of the people rather than its dilution. ${ }^{80}$ The transfer of (at least some) competences to the supranational level is thus fully compatible with the constitutional principle of sovereignty.

In the most recent Lisbon Treaty judgment, the Polish Constitutional Tribunal (PCT) applied a similar argument and further elaborated it. In setting the parameters for review, the PCT first declared that sovereignty could no longer be perceived as an absolute and unrestricted power free from external influences, since the freedom of state activity is now subjected to various restrictions imposed by international law. ${ }^{81}$ According to the PCT, these restrictions are particularly visible in the case of the EU legal order, given the binding character of EU law and its direct impact on internal relations between the Member States, as well as the broader scope of competences that the Union enjoys in comparison with other international organisations. ${ }^{82}$ However, instead of regarding it as a limitation of state sovereignty, the PCT argued that membership in the EU and the assumed obligations should be viewed as a manifestation of state

\footnotetext{
75 For an English translation, see Case 6603-2004 before the Spanish Tribunal Constitucional (Spanish EU Constitutional Treaty case) (2005) 1 CMLR 39.

76 ibid, para 37.

77 See Press Release (n 63).

78 See the English translation of Case 2008-35-01 before the Constitutional Court of Latvia (Latvian Lisbon Treaty) (2010) 1 CMLR 42.

79 ibid, para 173.

80 ibid, para 225.

81 See Polish Lisbon Treaty (n 64) point 2.1.

82 ibid.
} 
sovereignty. ${ }^{83}$ This, according to the PCT, follows from the fact that EU membership has allowed the Member States to extend their activities into fields where they had not been present before. ${ }^{84}$

Simply put, all these judgments confirm that highest national courts have renounced the inflexible, high-handed conception of sovereignty, by allowing for a transfer of sovereign powers to the supranational level. This comes as no surprise from either the doctrinal or practical point of view. As explained above, nearly all legal scholars nowadays agree that sovereignty can no longer be conceived as an absolute, indivisible and perpetual power of lawmaking. In this regard, the 'looser' interpretation of the principle of sovereignty in judicial practice, or at least its negative meaning, seems to correspond to how it is understood in legal doctrine.

Besides, this kind of interpretation of the national constitutional principle of sovereignty would appear to be the only legally and politically viable one. Legally, the courts' choice was limited by the texts of their own respective constitutions, which explicitly allow for the transfer of powers from national to the supranational level. ${ }^{85}$ Politically, their choice was limited since any other, more rigid interpretation of the principle of sovereignty would have doomed the project of European integration to failure.

Yet, despite the courts' renouncement of the old-fashioned understanding of this principle, they did nonetheless insist on preserving the essence or core of national sovereignty in the process of European integration. This raises the question: if sovereignty should no longer be conceived in traditional and absolute terms, how exactly should it be construed from a practical point of view? In that regard, what do the core national sovereign powers consist of and what does their preservation imply?

Regrettably, the national case law reviewing Treaty amendments for their compatibility with national constitutional laws does not provide

\footnotetext{
83 ibid.

84 In that regard, the Court has also stressed that EU membership has not led to a permanent limitation or loss of sovereign rights of the Member States, given the fact that they have merely assumed an obligation to jointly conduct state duties in areas of cooperation, that the conferral of state competences on the Union is not irrevocable, that the Member States maintain the ultimate competence to 'determine competences', as well as the fact that Member States' constitutions, which are the manifestations of state sovereignty, retain their significance (ibid).

85 See Article 10a of the Czech Constitution, Article 20 of the Danish Constitution, Article 88.2 of the French Constitution, Article 24 of the German Basic Law, Article 2/A of the Hungarian Constitution, Article 68 of the Latvian Constitution, Article 90 of the Polish Constitution and Article 93 of the Spanish Constitution. For further discussion, see de Witte (n 8) 150-155; and Monica Claes, The Europeanization of National Constitutions in the Constitutionalisation of Europe: Some Observations Against the Background of the Constitutional Experience of the EU-15' (2007) 3 CYELP 1.
} 
much clarity in this respect. Rather, it exposes a world of ambiguity surrounding the principle of sovereignty in legal practice.

To begin with, the majority of the courts which relied on the principle of sovereignty in their reviews of primary EU law amendments have failed to elaborate what exactly this principle entails. Most of these analysed cases thus leave it entirely up in the air as to which core features of sovereignty national governments and legislators should seek to preserve in the process of European integration.

While this is regrettable from the perspective of the achievement of legal clarity and certainty, it is not particularly surprising. The reason for the reluctance of the highest national courts to clarify what the principle of sovereignty comprises lies precisely in its ambiguous character. This was explicitly acknowledged by one of the national tribunals which relied on sovereignty in its constitutionality review of primary EU law amendments - namely, the Czech Constitutional Court in its Lisbon Treaty judgment. In particular, the Czech court explained that due to the fact that state sovereignty constitutes a highly disputed term and a very difficult one to define in the abstract, it would refrain from its detailed interpretation in its judgment. ${ }^{86}$

Interestingly, however, and despite its acknowledgement of such a nature of sovereignty, the Czech Constitutional Court nonetheless engaged in a rather elaborate discussion of the contemporary meaning of this principle in its Lisbon Treaty case. The German Federal Constitutional Court and the Polish Constitutional Tribunal, in the course of their review of Lisbon Treaty amendments, have done the same.

The conclusion one can draw from these judicial attempts to provide an interpretation of sovereignty is that different courts may have a different understanding of this principle. Moreover, and more confusingly, these examples from judicial practice would seem to suggest that not only in different jurisdictions do different conceptions of sovereignty apply, but also that several different conceptions of sovereignty may be operating within one single jurisdiction.

An indicative example of this is the Czech Lisbon Treaty case, in which the Czech Constitutional Court recognised what appear to be different understandings of sovereignty. Specifically, in its judgment, the Czech Court acknowledged the conception of sovereignty of the people,${ }^{87}$ the sovereignty of the Member States, ${ }^{88}$ and, supposedly, in that con-

\footnotetext{
86 See para 98 of the Czech Lisbon Treaty case (n 61).

87 ibid, eg paras 93, 209.

88 ibid, para 102.
} 
text, the sovereignty of the Czech Republic as a state, ${ }^{89}$ the conception of pooled sovereignty, ${ }^{90}$ and the conception of practical sovereignty. ${ }^{91}$ Yet, in line with its recognition of the disputed character of sovereignty and the difficulty of defining it in the abstract, the Czech Court refrained from providing an explanation of the exact terms of each of the mentioned conceptions. As a result, the Czech Lisbon Treaty case leaves us in doubt as to what the principle of sovereignty means from the perspective of Czech constitutional law and in the particular context of European integration.

This, unfortunately, is not where the confusion and uncertainty regarding the contemporary meaning of the principle of sovereignty in legal practice ends. Aside from the inventive invocations of different conceptions of sovereignty by a single court in a single judgment, what causes further ambiguity is the fact that different courts seem to endorse what appear to be different interpretations of one (seemingly) overarching conception of sovereignty.

The most indicative examples of this, in relation to the conception of popular sovereignty, can be found in the Czech, Polish and German Lisbon Treaty cases. These courts seem to recognise two contemporary understandings of the sovereignty of the people: one grounded on the right to collective self-determination, and the other grounded on the right to individual self-determination.

First, there is the conception of popular sovereignty grounded on the right to collective self-determination and the supporting theory of necessary state tasks, traces of which can be found in the Polish and the German Lisbon Treaty cases. ${ }^{92}$ According to this understanding, the sovereignty of the people reflects and manifests itself in the right of the people as a collective, as a national political community, to self-determination. This collective right to self-determination is considered to be exercised through democratic participation and representation rights, allowing the people as a whole to voice their political interests and concerns through representative state institutions. It is considered that, by exercising their democratic rights, people authorise representative state organs to protect and advance their self-determinative choices through the performance of so-called necessary state tasks. Performance of these vital functions by state organs is, in turn, regarded as an affirmation of the people's right to self-determination and a consequent confirmation of their sovereign powers.

\footnotetext{
89 ibid, para 209.

90 ibid, para 104.

91 ibid, para 107.

92 See also Jürgen Habermas, The Crisis of the European Union: A Response (Polity Press 2012) 17-18.
} 
Despite the fact that the people as a collective are seen as the ultimate holders of sovereignty, under this conception the focus of normative concern shifts towards the state, its organs and their regulatory powers. This follows from the understanding that the sovereign powers of the people are expressed primarily through the performance of necessary state tasks by national institutions. What thus matters under this conception of popular sovereignty, especially in the European integration context, is the retention of these vital competences in the hands of the state. Their transfer to the supranational level would, under this understanding, result in an impermissible limitation or even loss of the sovereignty of the people.

In their recent Lisbon Treaty rulings, the Polish and the German constitutional courts seem to have endorsed this particular understanding of popular sovereignty. The Polish Constitutional Tribunal explained that the sovereignty of the Republic of Poland implies a 'confirmation of the primacy of the Polish Nation to determine its own fate' and is 'expressed in the inalienable competences of the organs of the state'. ${ }^{93}$ The German FCC, similarly, elaborated that safeguarding sovereignty requires restricting the transfer of sovereign powers at the EU level, particularly in central areas that shape citizens' economic, cultural and social circumstances of life. ${ }^{94}$ This has, in turn, led these courts to engage in quite a detailed description of what these non-transferable and vital state competences entail. ${ }^{95}$

While this understanding of the sovereignty of the people focuses on the performance of inalienable, necessary state tasks by state organs, the alternative rests on a different set of premises. Under this alternative understanding of popular sovereignty, individuals and their self-determinative rights, rather than necessary state tasks, are placed at the centre of normative concern. According to this liberal conception, popular sovereignty finds a grounding in the right to individual self-determination, which is considered to pertain to the sphere of human dignity and freedom. ${ }^{96}$ More precisely, under this conception, what stands at the core of the sovereignty of the people is the right of every individual to freely deter-

93 See point 2.1 of the Polish Lisbon Treaty case (n 64).

94 See paras 248, 249, 251 of the German Lisbon Treaty case (n 58).

95 For a more detailed account of this unprecedented exercise in defining necessary state tasks and the resulting criticism in academia, see Daniel Halberstam and Christoph Möllers, 'The German Constitutional Court Says “Ja zu Deutschland!"' (2009) 10(8) German Law Journal 1241.

96 See further Jürgen Habermas, 'Constitutional Democracy: A Paradoxical Union of Contradictory Principles?' (2001) 29(6) Political Theory 766; and Jürgen Habermas, The Crisis of the European Union: A Response (Polity Press 2012) 18. See also Nico Krisch, Beyond Constitutionalism: The Pluralist Structure of Postnational Law (OUP 2010) 92-94, 99, 282. 
mine his or her own personal fate. ${ }^{97}$ This right is ultimately considered to be based on the basic rights of individuals to human dignity and freedom. By the same token, the rights to democratic representation and participation, enabling individuals to exercise their right to self-determination, are also seen as derivatives of those basic rights. ${ }^{98}$

What thus matters under this liberal conception of popular sovereignty is the protection of rights to individual self-determination, dignity and freedom. Whether these rights are granted and protected at the national or the supranational level makes no difference in terms of advancing the sovereignty of the people. Therefore, rather than requiring the retention of certain necessary tasks at the national level, this understanding of the sovereignty of the people supports legal regulation in any given policy field and at any given level of governance, as long as such regulation advances self-determinative choices and prerogatives of individuals, and boosts their human dignity and freedom.

Amongst other conceptions of sovereignty, the Czech Constitutional Court in its Lisbon Treaty case seemed to have recognised this conception of popular sovereignty. This is seen in its description of human freedom and human dignity as values that form the foundation of a human being's self-determination, ${ }^{99}$ and in its interpretation of the sovereignty of the people as a mechanism built to protect inherent, inalienable, nonprescriptible, and non-repealable fundamental rights and freedoms of individuals, equal in dignity and rights'. ${ }^{100}$ Yet, as mentioned before, the $\mathrm{CCC}$ also relied on other conceptions of sovereignty, making it hard to determine exactly how the principle of sovereignty should be construed under Czech constitutional law.

As for the supranational counterpart of the highest national tribunals - the Court of Justice of the European Union (CJEU) - and its understanding of the principle of sovereignty in the European integration context, it is hard to discern what exactly it consists of. Unlike in the case of the Czech Constitutional Court, this is not due to the CJEU's endorsement of what appear to be different conceptions of sovereignty. Rather, this is due to the CJEU's unwillingness to address the issue of sovereignty in the EU and to elaborate its own understanding of this principle. ${ }^{101}$

\footnotetext{
${ }_{97}$ Consequently, 'the people' are under this conception understood as a self-determining community of free and equal citizens rather than a monolithic collective. See Habermas, 'Constitutional Democracy' (n 96) 778.

98 As Habermas explains, under this conception, we 'conceive democratic self-determination as an uncoerced process of ethical-political self-understanding undertaken by a populace accustomed to freedom'. Habermas, 'Constitutional Democracy (n 96) 771.

99 Para 103 of the Czech Lisbon Treaty case (n 61).

100 ibid, para 93.

101 de Witte (n 8) 154-155.
} 
The only conclusion one can draw from its case law is that the CJEU seems to share the national courts' view on the negative meaning of this principle. That is to say, the CJEU seems to agree that the principle of sovereignty should not be conceived in high-handed and absolute terms. Rather, in the context of European integration, it should be interpreted as allowing for the possibility of limitation and transfer of sovereign powers - at least to a certain point.

This view is substantiated by the CJEU's landmark judgments Van Gend en Loos and Costa $v$ ENEL, in which the formula used was that the Member States have limited their sovereign rights for the benefit of the European Union and its institutions, albeit within limited fields. ${ }^{102}$ Yet, while this provides further proof of the renouncement of an inflexible conception of sovereignty, and therefore confirms what the current understanding of sovereignty is not, it tells us little about what it is in today's European legal context.

It can thus be concluded that the profound vagueness and dispute concerning the contemporary understanding of the principle of sovereignty exists virtually at the same degree in legal practice as it does in legal doctrine. The only point of clarity and consensus regarding this principle would seem to concern its negative meaning. Accordingly, sovereignty should no longer be envisioned in Bodin's original terms as an absolute, indivisible, and perpetual power of lawmaking. How it should be properly construed in the present European legal context, unfortunately, remains far from settled.

\section{Conclusion}

In light of the unceasing trend to invoke the principle of sovereignty in debates regarding the scope, size and content of the European integration project, the aim of this paper was to answer what we know about the understanding of sovereignty in the EU today, and how this knowledge should inform our actions tomorrow.

It has been shown that from both a practical and doctrinal point of view, it is impossible to determine conclusively what sovereignty is considered to comprise in the present European legal context. This is not only made implicit through the various divergent interpretations of this principle in legal doctrine and judicial practice. It is also made explicit by the scholarly acknowledgement of the profoundly disputed character of

${ }^{102}$ See Case 26/62 Van Gend en Loos [1963] ECR 1, 12; and Case 6/64 Costa v ENEL [1964] ECR 585, 593. See also de Witte (n 8) 154-155. 
the notion this principle rests upon, ${ }^{103}$ as well as by the judicial acknowledgement of the difficulty of defining the term sovereignty in the abstract.

The only point of clarity regarding the contemporary interpretation of sovereignty is that the principle should no longer be conceived in traditional, inflexible and absolute terms, since this would be incompatible with the current European legal and political reality. Yet, while there seems to be an agreement regarding the negative meaning of sovereignty, we are far from reaching one regarding its positive meaning.

The principle of sovereignty thus remains a phantom chameleon straddling the territories of legal doctrine and constitutional practice. While this does not per se render it dangerous, it does put into question the role, strength and credibility of this curious creature. By extension, it puts into question the potency and persuasiveness of arguments that rely on it. Namely, due to its acknowledged ambivalent and highly disputed character, references to sovereignty would seem to muddle and weaken, rather than support and clarify, legal answers to any practical problems associated with moral legitimacy.

Besides providing a feeble basis for constructing legal arguments, the profoundly diluted and disputed character of sovereignty also casts doubt on the adequacy of using this principle as a legal parameter for determining the future of the European integration project. Since the ambiguity and disagreement surrounding sovereignty can facilitate the use of its divergent conceptions, reliance on this principle can easily generate opposing legal claims depending on the context and interests that one seeks to protect. ${ }^{104}$

\footnotetext{
${ }^{103}$ Besson has, in that regard, argued that the concept of sovereignty not only amounts to a complex and normative concept, but also that it is an essentially contestable concept. As such, it is a concept that not only expresses a normative standard and whose conceptions differ from one person to the other, but whose correct application is to create disagreement over its correct application or, in other words, over what the concept is itself. Samantha Besson, 'Sovereignty in Conflict' (2004) 8(15) European Integration online Papers, 6 <http:// eiop.or.at/eiop/texte/2004-015.htm> accessed 8 October 2014. See also Dan Sarooshi, International Organizations and Their Exercise of Sovereign Powers (Oxford Monographs in International Law Series, OUP 2005); and Hent Kalmo and Quentin Skinner (eds), Sovereignty in Fragments: The Past, Present and Future of a Contested Concept (CUP 2010). On the vague and complex character of the notion of sovereignty, see also Anneli Albi and Peter Van Elsuwege, "The EU Constitution, National Constitutions and Sovereignty: An Assessment of a "European Constitutional Order"' (2004) 29(6) EL Rev 741, 755-6; Roland Bieber, 'An Association of Sovereign States' (2009) 5 EuConst 391 399; de Benoist (n 14) 99; Bernd Krehoff, 'Legitimate Political Authority and Sovereignty: Why States Cannot be the Whole Story' (2008) 14 Res Publica 283, 288-9.

104 For a detailed explanation of how divergent conceptions of sovereignty can generate opposing results of legal analysis, in the context of a national constitutional review of EU law amendments, see Oršolić Dalessio (n 53) ch III.
} 
As such, the principle of sovereignty provides an ideal tool for arbitrary, incoherent and non-transparent policy-making under the pretence of legal neutrality. As some authors have already observed, sovereignty is not only too vague to be a helpful decision-making tool when deciding how we should deal with any particular problem which confronts us, ${ }^{105}$ but it is also ripe for political exploitation and is, in fact, often used for that exact purpose. ${ }^{106}$

Such a deeply ambiguous nature of sovereignty and the ongoing dispute surrounding it teaches us an important lesson: legal arguments that rely on this principle should not be taken at face value. Rather, they should be approached with extreme caution, a critical eye and full awareness of their open-ended potential. This should especially be done in cases where the principle of sovereignty is used as a legal standard of review capable of redefining the entire course of European integration. ${ }^{107}$

\footnotetext{
${ }^{105}$ Konrad Schiemann, 'Sovereignty: A Concept Creating Confusion' (Eutopia Law, 11 March 2013) <http:/ / eutopialaw.com/2013/03/11/sovereignty-a-concept-creating-confusion/> accessed 2 October 2014. Although Schiemann referred to the notion of sovereignty when he argued this, the quotation seems to fit, since his argument can be easily extended to the principle of sovereignty, which rests on this very notion.

106 Jessica Simor, 'Sovereignty: The Historical Perspective; or 'les absents ont toujours tort' (Eutopia Law, 7 March 2013) <http://eutopialaw.com/2013/03/07/sovereignty-thehistorical-perspective-or-les-absents-ont-toujours-tort/\#more-1809> accessed 2 October 2014.

${ }^{107}$ This is not to suggest that the notion of sovereignty should be given up in its entirety. The appeal of resorting to sovereignty-related rhetoric in public discourse will surely persist, given its strong traditional, emotional and symbolic overtone. It would be somewhat naïve to expect this to change due to any arguments of law or logic. Yet, when it comes to legal arguments and decisions capable of changing the entire course of European integration, expectations are different. Because of the immediate and real impact that such decisions may have on people's lives, they should be made prudently and transparently. A suggestion to abandon sovereignty-based arguments in legal discourse should thus be further explored.
} 